\title{
Yield and technological performance of sugarcane cultivars grown under Af climate conditions
}

\section{Desempenho produtivo e características tecnológicas de cana-de- açúcar plantadas em condições climáticas Af}

\author{
Augusto Sousa Miranda ${ }^{1}$; Felipe Nogueira Domingues ${ }^{2 *}$; Bruno Spacek Godoy ${ }^{3}$; \\ Aníbal Coutinho do Rêgo ${ }^{2}$; Cristian Faturi ${ }^{2}$; Jorge Cardoso de Azevedo ${ }^{4}$
}

\begin{abstract}
Sugarcane crops are grown in almost all regions of Brazil, in various types of soil and under the influence of different climate conditions, which results in diverse production environments as climate factors directly influence the yield and technological quality of a sugarcane crop. The present study evaluated the agronomic and technological characteristics of sugarcane cultivars grown in Af climate conditions. The agronomic traits (natural matter production and the number, length, and diameter of stalks) and technological attributes (Brix, purity, Pol, reducing sugars, total reducing sugars, moisture, and fiber content) of three sugarcane cultivars, IACSP93-6006, RB83-5486, and SP79-1011, were determined in a three-year experiment with a randomized block design using four blocks and two repetitions per block. The cultivars IACSP93-6006 and SP79-1011 exhibited superior agronomic traits compared to RB83-5486, showing better adaptation to the soil and climate conditions of the study area. However, the technological attributes, which were below the minimum standard levels required by the sugar and ethanol industry, were not statistically different among the studied cultivars. The abundant rainfall and high temperatures, characteristics of an Af climate, were not favorable for sucrose accumulation in the IACSP93-6006, RB83-5486, and SP79-1011 cultivars. Therefore, despite the high yield, sugarcane intended for industrial purposes should not be grown under Af climate conditions, owing to the insufficient technological parameters.
\end{abstract}

Key words: Maturation. Precipitation. Saccharum officinarum.

\section{Resumo}

A cana-de-açúcar é cultivada em quase todas as regiões do Brasil, em vários tipos de solo e sob a influência de diferentes condições climáticas, resultando em diversos ambientes de produção, sendo que fatores climáticos influenciam diretamente na produtividade e na qualidade tecnológica da canade-açúcar. Objetivou-se avaliar as características agronômicas e tecnológicas de cultivares de canade-açúcar cultivadas em condições climáticas tipo Af. Foram utilizadas três cultivares de cana-deaçúcar: IACSP93-6006, RB83-5486 e SP79-1011. O experimento foi realizado em delineamento em blocos casualizados, com quatro blocos e duas repetições por bloco. Na avaliação agronômica foram determinados a produção de matéria natural, número de colmos, comprimento do colmo e o diâmetro

1 Discente de Mestrado, Programa de Pós-Graduação em Ciência Animal, PPGCAN, Universidade Federal do Pará, UFPA, Castanhal, PA, Brasil. E-mail: augusto@veterinario.med.br

2 Profs., Universidade Federal Rural da Amazônia, UFRA, Belém, PA, Brasil. E-mail: felipend@gmail.com; anibalcr@gmail. com; cfaturi@ig.com.br

3 Prof., Universidade Federal do Pará, UFPA, Belém, PA, Brasil. E-mail: bspacek@gmail.com

4 Zootecnista, UFRA, Belém, PA, Brasil. E-mail: jorgec.azevedo1@gmail.com

* Author for correspondence 
do colmo. Quanto aos atributos tecnológicos foram determinados Brix, pureza, Pol, açúcares redutores, açúcares redutores totais, umidade e fibra. Houve diferença para as características agronômicas, produção de matéria natural, número de colmos, comprimento do colmo e diâmetro do colmo, com destaque para as cultivares IACSP93-6006 e SP79-1011, que demonstraram adaptação às condições edafoclimáticas da região. Não houve diferença para os atributos tecnológicos, Pol, Brix, açúcares redutores, pureza, açúcares redutores totais, fibra e umidade, cujos valores ficaram abaixo do padrão mínimo exigido pela indústria de produção de açúcar e álcool, evidenciando que as condições climáticas não foram favoráveis ao acúmulo de sacarose, pois no clima tipo Af a precipitação pluviométrica e temperatura são elevadas. As cultivares apresentaram altas produções por hectare, no entanto, os parâmetros tecnológicos foram insuficientes para serem usados na indústria sucroalcooleira.

Palavras-chave: Maturação. Precipitação. Saccharum officinarum.

\section{Introduction}

Sugarcane cultivation is experiencing rapid growth throughout Brazil. The planted area has substantially increased to meet the ethanol demand of large economies that are interested in renewable fuels (Brinkman et al., 2018). In recent years, plant breeding programs have contributed to the development of the sugarcane crop in Brazil, by developing new cultivars that have an improved yield and quality (Dal-Bianco et al., 2012).

Sugarcane crops are grown in all regions of Brazil, in various types of soil and under the influence of different climate conditions, which results in diverse production environments (Salgado, Carlucci, Bonacim, Novi, \& Pacagnella, 2014). Climate factors directly influence the yield and technological quality of a sugarcane crop (Cardozo \& Sentelhas, 2013; Silva, Borges, \& Albuquerque, 2014), primarily due to the edaphic-climatic conditions, crop management, and selected variety. Different sugarcane cultivars may have distinct yields and technological attributes, depending upon the production environment (Inman-Bamber, Bonnett, Spillman, Hewitt, \& Xu, 2009; Oliveira et al., 2014). Therefore, the crop must be studied in different development/production environments, to decipher the best cultivar and management strategy for each production environment.

Studies concerning the yield and technological attributes of sugarcane have been conducted in different climates, including As (Abreu, Silva,
Teodoro, Holanda, \& Sampaio, 2013), Aw (Cruz et al., 2010; Rhein et al., 2016), Awi (Caione et al., 2011), Cfa (Schwerz et al., 2017), and Cwa (Macêdo et al., 2012). However, information regarding the behavior of the sugarcane plant under Af climate conditions, which is characterized by abundant rainfall throughout the year and no dry season, is still required.

This study evaluated the agronomic traits and technological attributes of three sugarcane cultivars grown under Af climate conditions.

\section{Materials and Methods}

\section{Experimental site}

The study was performed at the Animal Reproduction Biotechnology Center (Central de Biotecnologia de Reprodução Animal - CEBRAN), located in the city of Castanhal $(65 \mathrm{~m}$ altitude; $01^{\circ} 18^{\prime} \mathrm{S}$ and $47^{\circ} 55^{\prime} \mathrm{W}$ ), state of Pará, Brazil, which has an Af climate, according to the Köppen-Geiger climate classification (Alvares, Stape, Sentelhas, Gonçalves, \& Sparovek, 2014). During the experimental period (June 2010 to October 2013), the annual climatological averages were: 3044.2 $\mathrm{mm}$ of rainfall, mean temperature of $26.8^{\circ}$, mean minimum temperature of $22.2^{\circ}$, mean maximum temperature of $34.1^{\circ}$, and $80 \%$ relative humidity (Figure 1, Table 1).

The sugarcane cultivars studied, IACSP93-6006, RB83-5486, and SP79-101, were donated by 
the Federal Institute of Education, Science, and Technology of the state of Pará (Instituto Federal de Educação, Ciência e Tecnologia do Pará), campus of Castanhal. These cultivars were chosen for the study as they are commonly grown in the study region.

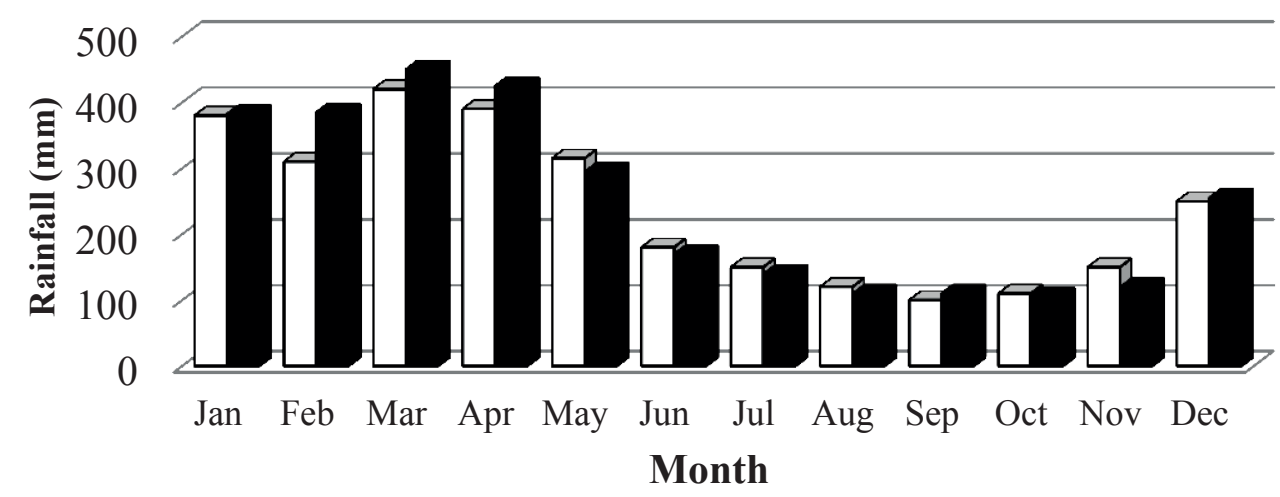

$\square$ Mean rainfall in the 3 years of the experiment Mean rainfall in the last 30 years

Figure 1. Average rainfall of the last 30 years and during the experimental period (average of three years) in the study area. Source: data provided by the automatic weather station of the National Institute of Meteorology (Instituto Nacional de Meteorologia - INMET), Belém, state of Pará (2014).

Table 1

Mean, maximum, and minimum temperatures over the last 30 years and during the experimental period (average of the three years) in the study area

\begin{tabular}{ccccccc}
\hline \multirow{2}{*}{ Months } & \multicolumn{3}{c}{$\begin{array}{c}\text { Mean temperature }\left(^{\circ}\right) \\
\text { over the last 30 years }\end{array}$} & \multicolumn{3}{c}{$\begin{array}{c}\text { Mean temperature }\left(^{\circ}\right) \\
\text { of the experimental period }\end{array}$} \\
\cline { 2 - 7 } Jan. & Mean & Maximum & Minimum & Mean & Maximum & Minimum \\
\hline Feb. & 26.0 & 31.0 & 22.7 & 26.2 & 34.1 & 21.8 \\
Mar. & 25.8 & 30.7 & 22.8 & 26.1 & 33.9 & 22.2 \\
Apr. & 25.9 & 30.7 & 23.0 & 26.3 & 34.3 & 22.4 \\
May & 26.2 & 31.1 & 23.1 & 26.4 & 33.7 & 22.2 \\
June & 26.5 & 31.8 & 23.1 & 26.7 & 33.8 & 22.7 \\
July & 26.5 & 31.9 & 22.8 & 26.7 & 33.7 & 22.1 \\
Aug. & 26.3 & 32.0 & 22.4 & 26.7 & 33.4 & 22.2 \\
Sept. & 26.7 & 32.5 & 22.5 & 27.1 & 34.3 & 22.2 \\
Oct. & 26.8 & 32.7 & 22.5 & 27.3 & 34.8 & 22.2 \\
Nov. & 27.0 & 32.6 & 22.4 & 27.3 & 34.6 & 22.0 \\
Dec. & 27.1 & 32.6 & 22.7 & 27.4 & 34.5 & 22.1 \\
\hline
\end{tabular}

Source: data provided by the automatic weather station of the National Institute of Meteorology (Instituto Nacional de Meteorologia - INMET), Belém, state of Pará (2014). 


\section{Treatments and design}

The treatments consisted of three sugarcane cultivars (IACSP93-6006, RB83-5486, and SP79101) in an experiment conducted over three years in a completely randomized design with two blocks (spatial and temporal) and eight replicates per treatment (four blocks and two repetitions per block), totaling 24 experimental plots.
The experimental plots consisted of four rows (4 $\mathrm{m}$ in length), with $1 \mathrm{~m}$ spacings between the rows. The marginal rows and a $1 \mathrm{~m}$ length at the ends of the central rows were not considered in the crop evaluation, so only two linear meters of the two central rows from each plot were considered as the usable area. Soil chemical analyses were performed before the beginning of the experiment and after each harvest (Table 2).

Table 2

Analysis of the soil of the experimental area during the three years of study

\begin{tabular}{|c|c|c|c|c|c|c|c|c|c|c|c|}
\hline \multirow{2}{*}{ Year } & \multirow{2}{*}{$\mathrm{pH}$} & $\mathrm{OM}$ & $\mathrm{P}$ & $\mathrm{H}^{+}+\mathrm{Al}^{+3}$ & $\mathrm{Al}^{+3}$ & $\mathrm{Ca}^{+2}$ & $\mathrm{Mg}^{+2}$ & $\mathrm{~K}^{+}$ & SB & CEC & $\mathrm{V}$ \\
\hline & & $\mathrm{g} / \mathrm{kg}$ & $\mathrm{mg} / \mathrm{dm}^{3}$ & \multicolumn{7}{|c|}{---------------------mmolc/dm³'------------------------- } & $\%$ \\
\hline Year I & 5.1 & 35.0 & 18.0 & 4.1 & 0.0 & 1.2 & 0.4 & 0.6 & 1.7 & 5.7 & 29.0 \\
\hline Year II & 6.0 & 19.5 & 25.0 & 3.5 & 0.1 & 3.0 & 0.8 & 2.9 & 3.9 & 7.3 & 53.2 \\
\hline Year III & 6.7 & 24.0 & 26.0 & 3.6 & 0.1 & 2.2 & 0.5 & 3.1 & 2.8 & 6.4 & 43.0 \\
\hline
\end{tabular}

$\mathrm{pH}$ - hydrogen potential; $\mathrm{OM}$ - organic matter; $\mathrm{P}$ - phosphorus; $\mathrm{H}^{+}+\mathrm{Al}^{+3}$ - potential acidity; $\mathrm{Al}^{+3}$ - aluminum; $\mathrm{Ca}^{+2}$ - calcium; $\mathrm{Mg}^{+2}$ - magnesium; $\mathrm{K}^{+}$- potassium; SB - sum of bases; CEC - cation exchange capacity; and V\% - percentage of base saturation.

Dolomitic limestone $\left(2 \mathrm{t} \mathrm{ha}^{-1}\right)$ was applied 60 days before planting. During the tillage two harrowings were performed, the first using a disc harrow followed by a leveling harrow. Subsequently, furrows were opened $1 \mathrm{~m}$ apart, at a depth of 25 $\mathrm{cm}$. In June 2010, the stalks were manually planted and distributed in the furrows, such that the basal portion of a seedling was in contact with the apical portion of the subsequent one, at a density of 15-18 buds per linear meter and subsequently sectioned.

The amount of fertilizer used during planting, for the first and second ratoons, was calculated from the results of the soil analyses. To achieve a yield of $100 \mathrm{t} \mathrm{ha}^{-1}, 50,120$, and $120 \mathrm{~kg} \mathrm{ha}^{-1}$ of $\mathrm{N} ; 140,70$, and $40 \mathrm{~kg} \mathrm{ha}^{-1}$ of $\mathrm{P}_{2} \mathrm{O}_{5}$; and 140, 150, and $160 \mathrm{~kg} \mathrm{ha}^{-1}$ of $\mathrm{K}_{2} \mathrm{O}$ were directly applied in the furrows at the time of planting, and by broadcasting in the other years. Dolomitic limestone (1 t ha ${ }^{-1}$; PRNT 90\%) was applied during the second ratoon crop.
Weed control was accomplished through herbicide applications. For pre-emergence, the 3-(3,4-dichlorophenyl)-1,1-dimethylurea (500 $\mathrm{g} \mathrm{L}^{-1}$ ) herbicide was applied at $3 \mathrm{~L} \mathrm{ha}^{-1}$ after planting and at each harvest. Sixty days after planting, the 3-chloro-5-(4,6-dimethoxypyrimidin2-ylcarbamoylsulfamoyl)-1-methylpyrazole-4 carboxylic acid $\left(750 \mathrm{~g} \mathrm{~kg}^{-1}\right)$ herbicide was applied to control the purple nutsedge (Cyperus rotundus), at a dose of $17.1 \mathrm{~g} \mathrm{ha}^{-1}$. After 90 days, the $\mathrm{N}$-(phosphonomethyl) glycine $\left(480 \mathrm{~g} \mathrm{~L}^{-1}\right)$ herbicide was applied at a dose of $3.2 \mathrm{~L} \mathrm{ha}^{-1}$, whilst the rows were protected with tarpaulin to avoid herbicide contact with the sugarcane plants. The herbicides were manually applied using a backpack sprayer, and the operator was properly dressed in personal protective equipment. The crops were manually harvested during all crop cycles, when the plants were approximately 13 months old. 


\section{Measurements}

The agronomic traits were evaluated following the methods described by Miranda et al. (2015). The natural matter production (NMP), in $\mathrm{tha}^{-1}$, was measured after the harvesting and weighing of all plants from the usable area of the sugarcane bed (4 linear meters). To quantify the NMP, the whole plant was used. The number of stalks per linear meter (NStalk) was determined by counting all the stalks in the sugarcane bed of the usable area and dividing that number by the total length of the planting line. The stalk length (StalkL) was calculated considering the distance $(\mathrm{m})$ from the base to the upper end of the plant.

A caliper was used to measure the diameter of the central internode (Stalk diameter - StalkD in $\mathrm{cm})$. The StalkL and StalkD were both determined considering the same 20 stalks that were randomly selected among those harvested from the sugarcane bed of the usable area.

The technological parameters were analyzed at the Technology Laboratory of the Pará Pastoril e Agrícola S.A. - PAGRISA mill, located in the city of Ulianópolis, state of Pará. The Brix, purity, Pol, reducing sugars (RS), total reducing sugars (TRS), moisture, and fiber content were determined.

\section{Statistical Analyses}

The means were analyzed using an analysis of variance and compared with the Tukey's test at a $5 \%$ probability. To determine whether there were differences in the climate data during the experimental period, a non-parametric KolmogorovSmirnov test was performed at the $5 \%$ probability level.

\section{Results and Discussion}

Owing to the similar topography and soil of the experimental area, which was only $600 \mathrm{~m}^{2}$, and the fact that there were no differences in the rainfall or minimum temperatures during the experimental period, the results are discussed considering only the treatment effect (cultivars). Therefore, the blocks in the design were only considered to decrease the variance of the treatments and thus render the test more sensitive. The agronomical traits were statistically different among the cultivars $(\mathrm{p}<0.05)$, whilst the technological attributes were not.

All the cultivars presented a high NMP under the studied climate conditions; and the cultivars IACSP93-6006 and SP79-1011 were superior to RB83-5486. The NMP values found in this study were higher than those reported in studies performed under other climate conditions. The NMP of sugarcane crops grown under the Aw and Am climate conditions ranged from 58.8 to 136.9 $\mathrm{t} \mathrm{ha}^{-1}$ and 116.79 to $192.91 \mathrm{t} \mathrm{ha}^{-1}$, respectively (Capone, Lui, Silva, Dias, \& Melo, 2011; Oliveira et al., 2011). Macêdo et al. (2012) evaluated two sugarcane cultivars in a Cwa climate under irrigated and rainfed conditions during the drought period, where the highest NMP $\left(103.0 \mathrm{t} \mathrm{ha}^{-1}\right)$ was observed in the irrigated cultivation. In the same study, the RB83-5486 cultivar had an NMP of $84.0 \mathrm{t} \mathrm{ha}^{-1}$ under irrigated conditions (Macêdo et al., 2012), while in the present study, its NMP was $250.16 \mathrm{t} \mathrm{ha}^{-1}$.

In this study, the cultivar SP79-1011 had the highest NStalk among those evaluated (Table 3). The NStalk is positively correlated with the yield of sugarcane fields, meaning that a high Nstalk is an important agronomic trait. The NStalk is influenced by high temperatures $\left(25^{\circ}\right.$ to $\left.30^{\circ}\right)$ and solar radiation, which favor tillering and tiller senescence (Waclawovsky, Sato, Lembke, Moore, \& Souza, 2010). Thus, sugarcane crops grown under the environmental conditions evaluated in the present study tend to have a high NStalk, due to the high solar radiation and high mean temperature $\left(26.8^{\circ}\right)$ found in the low-latitude region $\left(01^{\circ} 18^{\prime} \mathrm{S}\right)$. The NStalk values observed in the present study were similar to those reported by Oliveira et al. (2011), who found 13 stalks per linear meter for sugarcane cultivars grown in an Aw climate. 
Table 3

Agronomic traits of sugarcane cultivars grown in an Af climate, average of three cuts

\begin{tabular}{lcccc}
\hline Variables & IACSP93-6006 & RB83-5486 & SP79-1011 & SEM \\
\hline NMP $\left(\mathrm{tMN} \mathrm{ha}^{-1}\right)$ & $339.02 \mathrm{a}$ & $250.16 \mathrm{~b}$ & $321.52 \mathrm{a}$ & 22.47 \\
NStalk $\left(\right.$ number linear $\left.\mathrm{m}^{-1}\right)$ & $13.29 \mathrm{a}$ & $12.05 \mathrm{a}$ & $15.28 \mathrm{~b}$ & 0.47 \\
StalkL $(\mathrm{m})$ & $3.77 \mathrm{a}$ & $3.73 \mathrm{a}$ & $3.49 \mathrm{~b}$ & 0.05 \\
StalkD $(\mathrm{cm})$ & $2.47 \mathrm{a}$ & $2.28 \mathrm{~b}$ & $2.35 \mathrm{~b}$ & 0.02 \\
\hline
\end{tabular}

NMP - natural matter production; NStalk - number of stalks; StalkL - stalk length; StalkD - stalk diameter; and SEM - standard error of mean.

The cultivars IACSP93-6006 and RB835486 had a higher StalkL than SP79-1011 ( $\mathrm{p}<$ 0.05). Shigaki et al. (2004) evaluated different sugarcane cultivars under drought conditions and found that a high humidity in the soil is the main factor responsible for greater elongation between internodes, which explains the high StalkL values observed in the present study. Capone et al. (2011) reported a StalkL ranging from 3.13 to $4.13 \mathrm{~m}$ in sugarcane grown under Am climate conditions, which are similar to those observed in the present study. However, the values reported by Capone et al. (2011) were observed after irrigation during the drought period. The cultivar IACSP93-6006 had a higher StalkD than the other cultivars.
According to Ferreira et al. (2017), morphological characteristics can be used to evaluate the development and adaptation of a crop to a certain environment. Considering the results previously described, we can state that all three cultivars evaluated in this study are adapted to Af climate conditions.

Although the agronomic traits were positively affected by the climate conditions, the technological attributes (Table 4) were negatively affected, i.e., the sucrose accumulation was inadequate compared to that described in other studies conducted in different climate conditions (Oliveira et al., 2012; Macêdo et al., 2012).

Table 4

Technological attributes of sugarcane cultivars grown in an Af climate, presented as the average of three cuts

\begin{tabular}{lccccc}
\hline Variables & IACSP93-6006 & RB83-5486 & SP79-1011 & Standard* & SEM \\
\hline Brix (\% juice) & 15.08 & 14.91 & 14.78 & $>18$ & 0.11 \\
Pol (\% juice) & 11.61 & 11.11 & 11.29 & $>14$ & 0.13 \\
Purity (\% juice) & 76.96 & 74.82 & 76.56 & $>85$ & 0.74 \\
RS (\% juice) & 1.68 & 1.64 & 1.65 & $<0.8$ & 0.03 \\
TRS (\% juice) & 14.54 & 14.43 & 14.31 & $>15$ & 0.12 \\
Moisture (\% sugarcane) & 71.72 & 71.19 & 71.80 & $<70$ & 0.23 \\
Fiber (\% sugarcane) & 13.18 & 13.65 & 13.52 & $11-13$ & 0.21 \\
\hline
\end{tabular}

Brix - content of soluble solids of sugarcane juice; Pol - sucrose content of sugarcane juice; RS - reducing sugars; TRS - total reducing sugars; *According to Ripoli and Ripoli (2004); and SEM - standard error of mean. 
The technological attributes determine the quality of the raw material for the sugar and ethanol industry and will define the sugar and ethanol yields. Comparing the technological attributes observed in the three cultivars evaluated in this study with the standard values for sugarcane processing in the sugar and ethanol industry, we verified that the sucrose accumulation in plants grown under Af climate conditions was inadequate. Thus, sugarcane cultivation in an Af climate for use in the sugar and ethanol industry is not recommended, which shows that climate factors directly affect the behavior of the crop.

The large volume of rainfall during the growing season prolonged the vegetative period, slowing the maturation and, consequently, reduced the sucrose concentration in the stalk. During the entire experimental period, the average total rainfall was $3044.18 \mathrm{~mm}$, with September the month with the lowest rainfall (106.6 mm), demonstrating that the cultivars did not suffer from water stress at any time during the experiment.

Two environmental factors act independently during sugarcane maturation, low temperatures, and water deficit. If the plant does not experience these stress conditions, it will vegetate and not accumulate sucrose (Hoffmann, 2010). A reduced temperature has a direct effect on the nutrient absorption, reducing the vegetative growth, causing the majority of the produced sugars to be stored (Scarpari \& Beauclair, 2009). Another factor that stimulates the accumulation of sucrose in sugarcane is the stress caused by water deficit, which reduces the soil humidity and, consequently, decreases the water content in the plant tissues (dehydration forces the conversion of the reducing sugars in sucrose). Cardozo, Sentelhas, Panosso and Ferraudo (2014) verified that the water content in the sugarcane stalk is inversely proportional to the sucrose content, and good water availability slows down the maturation process.
Oliveira et al. (2012) reported that a high humidity in the soil affects the sucrose accumulation of the plant, which is positively correlated with moisture and reducing sugars and negatively associated with sucrose. This situation was observed in the present study, in which the cultivars had high values of moisture and reducing sugars and an unsatisfactory sucrose accumulation, ratified by the low values of the Brix, Pol, ART, and purity parameters.

In an Am climate, Oliveira et al. (2012) obtained an average of $24.31 \%, 20.98 \%, 18.34 \%$, and $85.38 \%$ for the parameters of Brix, Pol, ART, and purity, respectively. The Brix for the cultivar RB83-5486, grown in an Aw climate, was $24.17 \%$ (Capone et al., 2011). On the other hand, Dantas, Figueredo, Farias, Azevedo and Azevedo (2006) reported Brix and Pol values of $19.08 \%$ and $17.75 \%$, respectively, for the cultivar SP79-1011 grown in an Aw climate. In the Am and Aw climate conditions there are drought periods, and the reduced rainfall results in a water deficit, which contributes to sugarcane maturation.

The fiber content of the cultivars is above the standard levels of the sugar and ethanol industry. Fiber is important for plant support, to avoid tipping. Under Af climate conditions, the cultivars had a high fiber content, but tipping still occurred, which prevented mechanic harvest. The values for the fiber content were higher than those observed by Oliveira et al. (2012) under Aw climate conditions, which ranged from $11.03 \%$ to $12.51 \%$. According to Oliveira et al. (2012), the longer the vegetative period lasts, the higher the fiber content.

\section{Conclusion}

The IACSP93-6006, RB83-5486, and SP791011 cultivars had high yields per hectare. However, the technological attributes were inadequate for the sugar and ethanol industry. Therefore, sugarcane intended for industrial purposes should not be grown under Af climate conditions. 


\section{Acknowledgements}

The authors would like to thank the Federal University of Pará for the financial support provided to conduct the research.

\section{References}

Abreu, M. L., Silva, M. A., Teodoro, I., Holanda, L. A., \& Sampaio, G. D., Neto. (2013). Crescimento e produtividade de cana-de-açúcar em função da disponibilidade hídrica dos Tabuleiros Costeiros de Alagoas. Bragantia, 72(3), 262-270. doi: 10.1590/ brag.2013.028

Alvares, C. A., Stape, J. S., Sentelhas, P. C., Gonçalves, J. L. M., \& Sparovek, G. (2014). Köppen's climate classification map for Brazil. Meteorologische Zeitschrift, 22(6), 711-728. doi: 10.1127/09412948/2013/0507

Brinkman, M. L. J., Cunha, M. P., Heijnen, S., Wicke, B., Guilhoto, J. J. M., Walter, A.,... Hilst, F. V. D. (2018). Interregional assessment of socio-economic effects of sugarcane ethanol production in Brazil. Renewable and Sustainable Energy Reviews, 88(2), 347-362. doi: 10.1016/j.rser.2018.02.014

Caione, G., Fernandes, F. M., Lange, A., Bergamaschine, A. F., Dalchiavon, F. C., \& Silva, A. F. (2012). Produtividade e valor nutricional de variedades de cana-de-açúcar sob diferentes fontes de fósforo. Semina: Ciências Agrárias, 33, suplemento 1, 28132824. doi: 10.5433/1679-0359.2012v33Supl1p2813

Capone, A., Lui, J. J., Silva, T. R., Dias, M. A. R., \& Melo, A. V. (2011). Avaliação do comportamento de quinze cultivares de cana-de-açúcar na região Sul do Tocantins. Journal of Biotechnology and Biodiversity, 2(3), 70-78. doi: 10.20873/jbb.uft. cemaf.v2n3.capone

Cardozo, N. P., \& Sentelhas, P. C. (2013). Climatic effects on sugarcane ripening under the influence of cultivars and crop age. Scientia Agricola, 70(6), 449456. doi: 10.1590/S0103-90162013000600011

Cardozo, N. P., Sentelhas, P. C., Panosso, A. R., \& Ferraudo, A. S. (2014). Multivariate analysis of the temporal variability of sugarcane ripening in southeastern Brazil. Crop \& Pasture Science, 65(3), 300310. doi: $10.1071 / \mathrm{CP} 13160$

Cruz, P. F., Figueiredo, M. P., Pereira, L. G. R., Bergamaschi, K. B., Rodrigues, C. S., \& Rech, C. L. S. (2010). Fracionamento e cinética da fermentação ruminal in vitro dos carboidratos de cinco variedades de cana-de-açúcar. Ciência Animal Brasileira, 11(4), 784-793. doi: 10.5216/cab.v11i4.4804

Dal-Bianco, M., Carneiro, M. S., Hotta, C. T., Chapola, H. P. H., Garcia, A. A. F., \& Souza, G. M. (2012). Sugarcane improvement: how far can we go? Current Opinion in Biotechnology, 23(2), 265-270. doi: 10.1016/j.copbio.2011.09.002

Dantas, J., Neto, Figueredo, J. L. C., Farias, C. H. A., Azevedo, H. M., \& Azevedo, C. A. V. (2006). Resposta da cana-de-açúcar, primeira soca, a níveis de irrigação e adubação de cobertura. Revista Brasileira de Engenharia Agrícola e Ambiental, 10(2): 283288. doi: 10.1590/S1415-43662006000200006

Ferreira, T. H. S., Tsunada, M. S., Bassi, D., Araújo, P., Mattiello, L., Guidelli, G. V.,... Menossi, M. (2017). Sugarcane water stress tolerance mechanisms and its implications on developing biotechnology solutions. Frontiers in Plant Science, 8(1), 1-18. doi: 10.3389/ fpls.2017.01077

Hoffmann., C. M. (2010). Sucrose accumulation in sugar beet under drought stress. Journal of Agronomy and Crop Science, 196(4), 243-252. doi: 10.1111/j.1439037X.2009.00415.X

Inman-Bamber, N. G., Bonnett, G. D., Spillman, M. F., Hewitt, M. L., \& Xu, J. (2009). Sourcesink differences in genotypes and water regimes influencing sucrose accumulation in sugarcane stalks. Crop \& Pasture Science, 60(4), 316-327. doi: 10.1071/CP08272

Macêdo, G. A., Costa, E. L., Viana, M. C. M., Ferreira, J. J., Pires, J. F., \& Freire, F. M. (2012). Características agronômicas e químicas das variedades de canade-açúcar RB83-5486 e RB86-7515 sob irrigação e sequeiro. Revista Brasileira de Engenharia Agrícola e Ambiental, 16(6), 599-603. doi: 10.1590/s141543662012000600002

Miranda, A. S., Domingues, F. N., Godoy, B. S., Oaigen, R. P., Rêgo, A. C., Faturi, C.,... Silva. F. (2015). Production and chemical composition of three sugarcane cultivars grown under Af climate conditions. Revista Brasileira de Zootecnia, 44(11), 384-389. doi: 10.1590/S1806-92902015001100002

Oliveira, F. M., Aspiazú, I., Kondo, M. K., Borges, I, D., Pegoraro, R. F., \& Vianna, E. J. (2011). Crescimento e produção de variedades de canade-açúcar influenciadas por diferentes adubações e estresse hídrico. Revista Trópica-Ciências Agrárias e Biológicas, 5(1), 56-67. 
Oliveira, F. M., Aspiazú, I., Kondo, M. K., Borges, I. D., Pegoraro, R. F., \& Vianna, E. J. (2012). Avaliação tecnológica de variedades de cana-de-açúcar influenciadas por diferentes adubações e supressões de irrigação. Revista Ceres, 59(6), 832-840. doi: 10.1590/S0034-737X2012000600014

Oliveira, F. M., Aguilar, P. B., Teixeira, M. F. F., Aspiazú, I., Monção, F. P., \& Antunes, A. P. S. (2014). Características agrotecnólogicas de cana-de-açúcar em diferentes épocas de supressão de irrigação e níveis de adubação. Semina: Ciências Agrárias, 35, (3), 1587-1606. doi: 10.5433/1679-0359.2014v35n $3 \mathrm{p} 1587$

Rhein, A. F. L., Pincelli, R. P., Arantes, M. T., Dellabiglia, W. J., Kölln, O. T., \& Silva, M. A. (2016). Technological quality and yield of sugarcane grown under nitrogen doses via subsurface drip fertigation. Revista Brasileira de Engenharia Agrícola e Ambiental, 20(3), 209-214. doi: 10.1590/1807-1929/ agriambi.v20n3p209-214

Ripoli, T. C. C., \& Ripoli, M. L. C. (2004). Biomassa de cana-de-açúcar: colheita, energia e ambiente. Piracicaba, SP: Barros \& Marques.

Salgado, A. P., Jr., Carlucci, F. V., Bonacim, C. A. G., Novi, J. C., \& Pacagnella, A. C., Jr. (2014). Investment potential for new sugarcane plants in Brazil based on assessment of operational efficiency. The International Food and Agribusiness Management Review, 17(2), 41-64.
Scarpari, M. S., \& Beauclair, E. G. F. (2009). Physiological model to estimate the maturity of sugarcane. Scientia Agricola, 66(5), 622-628. doi: 10.1590/S010390162009000500006

Schwerz, F., Elli, E. F., Behling, A., Schmidt, D., Caron, B. O., \& Sgarbossa, J. (2017). Yield and qualitative traits of sugarcane cultivated in agroforestry systems: Toward sustainable production systems. Renewable Agriculture and Food Systems, 32(6), 1-13. doi: $10.1017 / \mathrm{S} 1742170517000382$

Shigaki, F., Berto, A., Lima, E., Zonta, E., Ceddia, M. B., \& Freitas, N. (2004). Influência do estresse hídrico nos parâmetros de crescimento, acúmulo de nitrogênio e produtividade em diferentes variedades de cana-de-açúcar em Miracema - RJ. Revista Universidade Rural - Série Ciências Exatas e da Terra, 24(1), 18-25.

Silva, V. P. R., Borges, C. J. R., \& Albuquerque, W. G. (2014). Necessidades hídricas da canade-açúcar cultivada em clima tropical. Semina: Ciências Agrárias, 35(2), 625-632. doi: 10.5433/1679-0359.2014v35n2p625

Waclawovsky, A. J., Sato, P. M., Lembke, C. G., Moore, P. H., \& Souza, G. M. (2010). Sugarcane for bioenergy production: an assessment of yield and regulation of sucrose content. Plant Biotechnology Journal, 8(3), 263-76. doi: 10.1111/j.1467-7652.2009.00491.x 
